\title{
Sensorial Assessment of Beef Sausage Processed by Wheat Germ Flour
}

\author{
Elbakheet $\mathbf{S I}^{*}$, Elgasim EA and Algadi $\mathbf{M Z}^{2}$
}

Faculty of Agriculture, University of Khartoum, Sudan

\begin{abstract}
The term sausage is derived from the Latin word (salsus) meaning salt or literally translated, refers to chopped or minced meat preserved by salting. In this study beef sausage was processed by additions of different replacement levels of meat by wheat germ flour (WGF) replacement levels were: $0 \%$ (as control) $10 \%$ and $15 \%$. The processed beef sausages were packaged in foam trays, over wrapped with polyvinyl chloride (PVC) and stored refrigerated at $4{ }^{\circ} \mathrm{C} \pm 1$ for up to 7 days. Several variables were determined using subjective and objective measurements, to evaluate the effects of replacement levels and storage periods on the sensory attributes of the processed beef sausage. The evaluation was conducted immediately after processing, three and seven days post processing day. Results demonstrated that lower scores in over all acceptability, aroma and flavor; but higher score $(p<0.05)$ in deviation from meat aroma. Fifteen percent replacement level sample had the highest $(p<0.05)$ on overall acceptability, flavor and aroma scores. Overall acceptability score, flavor score and aroma score, were increase with the increased of replacement levels. WGF act as binder in beef sausage production and could be a good substitute to others plant binders which are used as meat binder or extenders.
\end{abstract}

Keywords: Sensory assessment; Sausage; Polyvinyl chloride; Processing

\section{Introduction}

Nutritionally, meat is a very good source of essential amino acids, to a lesser extent, of certain minerals. Although vitamins and essential fatty acids are also present, meat also provides calories from protein, fat and limited quantities of carbohydrate [1]. Germ constitutes about $2.5 \%$ of the grain weight and comprises minimal amount of protein, but greatest share of fat, vitamins especially tocopherols [2]. Wheat germ is a by-product of wheat milling, and recently, it has attracted much attention due to its unique nutritional value. It contains $42 \%$ to $45 \%$ carbohydrate, $25 \%$ to $30 \%$ protein, $16 \%$ simple sugars, $4 \%$ to $5 \%$ minerals (total ash) and $10 \%$ to $12 \%$ lipid [3]. The continues successes of marketing meat on the innovation and consistent production of high quality products. Consumers are looking for convenient food products with new/exciting flavor, textures etc. [4]. Meat and meat products are highly perishable materials so sanitation and cooling is essentials in handling, marketing and processing of meat. The sanitation in the Sudan, in general is very poor regarding slaughtering, handling, marketing and processing of meat, except for very few meat plant and slaughter houses. Generally, meat products are widely consumed throughout the world; but unfortunately, their cost is high. To reduce this cost there is increasing interest in use of various non-meat proteins especially plant protein. The objectives of this study to evaluate the effects of partial replacement of meat by wheat germ flour on the quality characteristics of beef sausage.

\section{Material and Methods}

\section{Materials}

Food materials: Meat loins and round were obtained from Animal Production Research Center Kuku. The beef meat was stored frozen at $-11 \pm 1^{\circ} \mathrm{C}$ in freezer at Regional Training Center for Meat Quality, Grading and Meat Technology, Elkadaro. Wheat germ was obtained from Seen flour mills stored frozen. Spices, salt and sugar were obtained from local market of Khartoum North. The additional fat needed in the formulation was obtained from the local market. Uniform rendered fat free of protein was used.

Chemicals and reagents: Chemicals and reagent used were brought from the central lab stores of Khartoum University, sodium nitrite and ascorbic acid, were obtained from Looly Company, Khartoum.

Casings: Cellulose casings $23 \mathrm{~mm}$ in diameter were obtained from Looly Company, Khartoum.

\section{Methods}

\section{Raw materials preparation}

Meat preparation: Stored beef was allowed to thaw and sliced then ground through a $0.75 \mathrm{In}$, plate using a meat grinder. Ground beef was stored refrigerated at $4^{\circ} \mathrm{C} \pm 1^{\circ} \mathrm{C}$, for about $20 \mathrm{hr}$, a sample was taken to be analyses for protein fat and moisture content following AOAC Method [5] (Table 1).

Wheat germ preparation: Stored wheat germ was ground, to form wheat germ flour (WGF). Then a sample was taken and analyzed for protein, fat and moisture content, following AOAC Method [5] (Table 1).

Calculation for sausage formulation: The experiment designed to produce sausage with the following specification, protein $15 \%$, fat $20 \%$ moisture, $58.3 \%$ added starch $4.7 \%$, salt $1.5 \%$, and spices $0.5 \%$ (Tables 2 and 3). Three batches with three replacements of meat by wheat germ were used every batch weight $2000 \mathrm{~g}$.

Therefore,

$$
\begin{aligned}
& \text { Protein required }=\frac{15 \times 2000}{100}=300 \mathrm{~g} \\
& \text { Fat required }=\frac{20 \times 2000}{100}=400 \mathrm{~g}
\end{aligned}
$$

*Corresponding author: Elbakheet SI, Faculty of Agriculture, University of Khartoum, Sudan, Tel: +249922544908; E-mail: shawgi1416@gmail.com

Received December 30, 2016; Accepted January 17, 2017; Published January 23, 2017

Citation: Elbakheet SI, Elgasim EA, Algadi MZ (2017) Sensorial Assessment of Beef Sausage Processed by Wheat Germ Flour. J Food Process Technol 8: 652 doi: $10.4172 / 2157-7110.1000652$

Copyright: (C) 2017 Elbakheet SI, et al. This is an open-access article distributed under the terms of the Creative Commons Attribution License, which permits unrestricted use, distribution, and reproduction in any medium, provided the original author and source are credited. 
Citation: Elbakheet SI, Elgasim EA, Algadi MZ (2017) Sensorial Assessment of Beef Sausage Processed by Wheat Germ Flour. J Food Process Technol 8: 652. doi: 10.4172/2157-7110.1000652

Page 2 of 3

\begin{tabular}{|c|c|c|c|c|c|c|c|}
\hline Material & Protein \% & Fat \% & Moisture content \% & Ash \% & Crude fibre \% & Carbohydrate & pH \\
\hline Beef meat & 22.6 & 3.2 & 71 & 0.98 & 0.3 & 2.29 \\
\hline Wheat germ & 27.2 & 9.3 & 10.35 & 2.17 & 2.53 \\
\hline
\end{tabular}

Table 1: Proximate analysis and $\mathrm{pH}$ of beef meat and wheat germ.

\begin{tabular}{|c|c|c|}
\hline Components & Percentage & Weight in gms \\
\hline Proteins & 15 & 300 \\
\hline Fat & 20 & 400 \\
\hline Starch & 4.7 & 94 \\
\hline Water & 58.3 & 1160 \\
\hline Salt & 1.5 & 30 \\
\hline Spices & 0.5 & 10 \\
\hline
\end{tabular}

Table 2: Sausage formula.

\begin{tabular}{|c|c|c|c|}
\hline \multirow{2}{*}{ Ingredient } & \multicolumn{3}{|c|}{ Replacement level of meat* } \\
\cline { 2 - 4 } & $\mathbf{0 \%}$ protein & $\mathbf{1 0 \%}$ protein & $\mathbf{1 5 \%}$ protein \\
\hline Beef meat & 1327.43 & 1194.7 & 1128.32 \\
\hline Wheat germ & - & 110.3 & 165.44 \\
\hline Starch & 94 & 94 & 94100 \\
\hline Fat & 357.52 & 355.15 & 94 \\
\hline Water & 217.53 & 300.34 & 341.3 \\
\hline Salt & 30 & 30 & 30 \\
\hline Sugar & 10 & 10 & 10 \\
\hline Black pepper & 3 & 3 & 3 \\
\hline Nutmeg & 2 & 2 & 2 \\
\hline Cinnamon & 2 & 2 & 2 \\
\hline Garlic & 2 & 2 & 0.11 \\
\hline Sodium nitrite & 0.13 & 0.12 & 0.52 \\
\hline Vitamin C & 0.62 & 0.55 & \\
\hline
\end{tabular}

Table 3: Sausage formulation for all treatments.

Water required $=\frac{58.3 \times 2000}{100}=1166 \mathrm{~g}$

Starch required $=\frac{4.7 \times 2000}{100}=94 \mathrm{~g}$

Salt required $=\frac{1.5 \times 200}{100}=30 \mathrm{~g}$

Spices required $=\frac{0.5 \times 200}{100}=10 \mathrm{~g}$

Sodium nitrite $100 \mathrm{ppm}$.

Vitamin C $0.466 \mathrm{~g} / \mathrm{kg}$

First replacement level: Wheat germ $0 \%$ so the required protein was $100 \%$ from meat beef therefore beef require $=\frac{300 \times 100}{22.6}=1327.43$

Fat in $1327.43 \mathrm{~g}$ beef $=\frac{3.2 \times 1327.43}{100}=42.48$

Fat to be added $=400-42.48=357.52$

Moisture in $1327.43 \mathrm{~g}$ beef $=\frac{71 \times 1327.43}{100}=942.47$

Moisture from starch $=6$

Total moisture $=948.47$

Moisture to be added $=1166-948.47=217.53$

Required sodium nitrite $=0.13 \mathrm{~g}$
Required Vitamin $\mathrm{C}=0.62 \mathrm{~g}$

Second replacement level: Wheat germ $10 \%$ so the required protein was $90 \%$ from beef and $10 \%$ from wheat germ

There fore beef required $=\frac{300 \times 90}{22.6}=1194.7$

Wheat germ required $=\frac{300 \times 10}{27.2}=110.3$

Fat in $1194.7 \mathrm{~g}$ beef $=\frac{3.2 \times 1194.7}{100}=38.23$

Fat in 110.3 wheat germ $=\frac{6 \times 110.3}{100}=6.62$

Total fat $=44.85$

Fat to be added $=400-44.85=355.15$

Moisture in $1194.7 \mathrm{~g}$ beef $=\frac{71 \times 1194.7}{100}=848.24$

Moisture in $110.3 \mathrm{~g}$ wheat germ $=\frac{10.35 \times 110.3}{100}=11.42$

Moisture in $100 \mathrm{~g}$ starch $=6$

Total moisture $=865.66$

Moisture to be added $=1166-865.66=300.34$

Sodium nitrite to be added $=0.12 \mathrm{~g}$

Vitamin $\mathrm{C}$ to be added $=0.56 \mathrm{~g}$

Third replacement: Wheat germ $15 \%$ so the required protein in $85 \%$ from beef $15 \%$ from wheat germ.

Therefore beef required $=\frac{300 \times 85}{22.6}=112.32$

Wheat germ required $=\frac{300 \times 15}{27.2}=165.44$

Fat in $1128.32 \mathrm{~g}$ beef $=\frac{3.2 \times 1128.32}{100}=36.11$

Fat in $165.44 \mathrm{~g}$ wheat germ $=\frac{6 \times 165.44}{100}=9.95$

Fat to be added $=400-46.04=353.96$

Moisture in $1128.32 \mathrm{~g}$ beef $=\frac{71 \times 1128.32}{100}=801.11$

Moisture in $165.44 \mathrm{~g}$ wheat germ $=\frac{10.35 \times 165.44}{100}=17.12$

Moisture in $100 \mathrm{~g}$ starch $=6$.

Total moisture $=824.23$

Moisture to be added $=1166-824.23=341.8$

Sodium nitrate $=0.11 \mathrm{~g}$ 


\begin{tabular}{|c|c|c|c|c|c|c|c|}
\hline \multirow{2}{*}{ Samples } & \multicolumn{2}{|c|}{ A } & \multicolumn{2}{|c|}{ B } & \multicolumn{3}{|c|}{ C } \\
\hline & Extremity like & moderately like & Like & slightly like & slightly dislike & dislike & Extremity dislike \\
\hline Aroma & -- & -- & -- & -- & -- & -- & -- \\
\hline Flavour & -- & -- & -- & -- & -- & -- & -- \\
\hline $\begin{array}{l}\text { Deviation from } \\
\text { meaty aroma }\end{array}$ & -- & -- & - & -- & -- & -- & -- \\
\hline Juiciness & -- & -- & - & -- & -- & -- & -- \\
\hline Tenderness & -- & -- & -- & -- & -- & -- & -- \\
\hline Overall acceptability & 7 & 6 & 5 & 4 & 3 & 2 & 1 \\
\hline
\end{tabular}

Table 4: Sensory evaluation form (Flavour, deviation from meat aroma, juiciness, tenderness, and overall acceptability. Using scores as follows: $7=$ Extremity like; 6 = moderately like; 5 =Like; 4 = slightly like; 3 = slightly dislike; 2 = dislike; 1 = Extremity dislike).

\begin{tabular}{|c|c|c|c|c|}
\hline \multirow{2}{*}{ Independent variables } & \multicolumn{3}{|c|}{ Replacement levels of meat by WGF } & \multirow{2}{*}{ S.E } \\
\cline { 2 - 4 } & $\mathbf{0 \%}$ & $\mathbf{1 0 \%}$ & $\mathbf{1 5 \%}$ & \\
\hline Taste & 4.5 & 4.95 & 5.6 & $\pm(0.34)$ \\
\hline Order & 4.6 & 5.05 & 5.65 & $\pm(0.3)$ \\
\hline Variation from meat taste & 5.20 & 4.60 & 5.15 & $\pm(0.19)$ \\
\hline Juiciness & 5.15 & 4.85 & 5.37 & $\pm(0.15)$ \\
\hline Tenderness & 5.20 & 5.35 & 5.85 & $\pm(0.2)$ \\
\hline Overall acceptability & 4.85 & 5.00 & 6.10 & $\pm(0.39)$ \\
\hline
\end{tabular}

Table 5: Sensory characteristic of cooked beef.

Vitamin $\mathrm{C}$ to be added $=0.52 \mathrm{~g}$

Sausage preparation: Minced meat, salt, sugar, minced fat, spices, vitamin C, sodium nitrate and half of calculated ice water were introduced to a Hobart Chopper; the Chopper was then started for about $4 \mathrm{~min}$. The added materials were dispersed uniformly. Then the ground wheat germ, starch were added together with the remainder of the calculated water. The entire mass was chopped for about $5 \mathrm{~min}$. then transferred to manual stuffer to be stuffed into cellulose casing of $23 \mathrm{~mm}$ in diameter and linked at lengths of $15 \mathrm{~cm}$. The framed sausage were heated in water at $98^{\circ} \mathrm{C}$ for about $40 \mathrm{~min}$, followed by immediate cooling in ice water, for $15 \mathrm{~min}$. The cooled processed sausage was peeled and packed in foam trays over-wrapped with polyvinyl chloride (PVC) and stored refrigerated for up to 7 days. The WGF replacement levels in beef sausage formulation and processing were performed following the same procedures explained above.

\section{Method of analysis}

Sausage were assessed at 0 day (i.e., immediately after processing) after three and seven days post processing.

Sensory evaluation: Ten member sensory panel consisting of M.Sc. and B.Sc. student of food science and technology Department, Faculty of Agriculture, University of Khartoum, semi-trained according to the procedure of Cross et al. [6]. The panel evaluated the cooked sausage sample with the different treatment for juiciness, tenderness, test, odor, differential from meat taste and over all acceptability. By mean of the scale ( 7 = Extremely like, $1=$ Extremely dislike), (Table 4$)$. Panelists received samples which were randomly numbered. Water at room temperature was made available to panel for cleaning the palate between the tested samples.

Statistical analysis: The data collected from the different treatments was subjected to analysis of variance and whenever appropriate the mean separation procedure of Duncan was employed [7]. The SAS program [8] Was used to perform the general linear model (GLM) analysis.

\section{Results and Discussion}

\section{Sensory evaluation}

The sensory evaluation of beef sausage extended with three replacement level is shown in (Table 5), the control samples scored high values in deviation from meat aroma that could be due to flavor of wheat germ flour. According to Canasambandam and Zayas [9] aroma and flavor are probably the most important attributes that influence the sensory properties of comminuted meat product extended with non-meat protein additives. Fifteen percent replacement levels had the highest score in: aroma, flavor, Juiciness, tenderness and over all acceptability among the treatment. Generally, it was relatively like control sample in juiciness and deviation from meat aroma, and these agrees with the finding of Canasambanadam and zayas [10] a trained panel found suggested an effect due to increasing levels of wheat germ protein flour on aroma and flavor of frankfurters. $10 \%$ replacement level sample usually, scores higher than $0 \%$ and less than $15 \%$ in: aroma, flavor, deviation from meat aroma, Juiciness, tenderness and over all acceptability.

\section{Conclusion}

The relative high scores of tenderness and Juiciness in the sample with replacement levels $15 \%$ may be due to high water binding of these samples. Judge et al. [1] indicated that many of the physical property of meat include color, texture and firmness of raw meat, Juiciness and tenderness of cooked meat are partially dependent on WHC. And mention that the portion of water present in free form and the ability of meat to bind water and factors that increase this ability will increase juiciness.

\section{References}

1. Judge MD, Albert ED, Forrest JC, Hedrick MB, Merkel RA (1990) Principle of meat science. (2ndedn), Kendall Hunt, Owa, USA

2. Anon (1987) Wheat facts. Official publications of National Association of Wheat Growers 10: 17 .

3. Majzoobi M, Ghias F, Farahnaky A (2015) Physicochemical assessment of fresh chilled dairy dessert supplemented with wheat germ. Int J Food Sci Technol.

4. Barbut S (2016) Principles of meat processing. The science of poultry and meat processing.

5. AOAC (1995) Official method of analysis (4thedn). Association of Officia Analytical Chemists, Washington DC

6. Cross HR, Moen R, Stanfield MS (1978) Guidelines for training and testing judges for sensory analysis of meat quality. J Food Technol 32: 48-54.

7. Steel RG, Torrie JH (1980) Principles and procedures of statistics. MC Grow Hill, New York, USA.

8. SAS (1988) SAS/ STAT users guide.

9. Canasambanadam R, Zayas JF (1992) Functionality of wheat germ protein in comminuted meat products as compared with corn germ and soy proteins. J Food Sci 57: 829-833.

10. Canasambanadam R, Zayas JF (1996) Frankfurters extended with whea germ protein: Sensory properties and consumers response. J Food quality 19: 423-435. 